p-ISSN 2615-286X | e-ISSN 2798-5075

DOI 1052646

\title{
HUBUNGAN ANTARA RESPON KEHILANGAN DENGAN TINGKAT KECEMASAN PADA LANSIA DI PANTI BINA LANJUT USIA JAYAPURA
}

\author{
Syahafiah Tanarubun ${ }^{1}$, Suriyani $^{2}$, Risna Ampulembang ${ }^{1}$ \\ ${ }^{1}$ Prodi Keperawatan Stikes Jayapura \\ ${ }^{2}$ Politeknik Kesehatan Jayapura \\ email: prodikep.stikesjypr@yahoo.com
}

\begin{abstract}
ABSTRAK
Kehilangan adalah kejadian secara universal yang sifatnya unik bagi setiapindividu yang mengalami suatu pengalaman dalam kehidupannya, sedangkan tingkat kecemasan merupakan manifestasi dari respon kehilangan yang dirasakan atau dialami secara emosional oleh seseorang dengan objek ancaman yang tidak begitu jelas. Penelitian ini bertujuan untuk mengetahui hubungan respon kehilangan dengan tingkat kecemasan pada lansia. Desain penelitian ini menggunakan deskriptif analitik dengan pendekatan cross sectional. Penelitian ini dilakukan pada tanggal 27-28 Juni 2016 di Panti Bina Lanjut Usia Jayapura. Teknik pengambilan sampel dalam penelitian ini dengan menggunakan total sampling sebanyak 43 lansia. Pengambilan data menggunakan kuesioner dan analisa data menggunakan uji korelasi Spearman Rho. Hasil penelitian menunjukkan bahwa respon kehilangan pada lansia di Panti yang menerima 42 lansia (100\%), dimana mayoritas mengalami kecemasan normal 38 lansia $(90,5 \%)$ dan yang mengalami kecemasan ringan 4 lansia (9,5\%). Lansia yang merespon kehilangan dengan kategori tidak menerima kehilangannya ada 1 lansia (100\%), dimana lansia ini mengalami kecemasan ringan. Hasil penelitian ini menunjukan Adanya hubungan yang kuat antara respon kehilangan dengan tingkat kecemasan pada lansia di Panti Bina Lanjut Usia $(p=0,004)$.Diharapkan bagi lansia dapat menghadapi respon kehilangan secara adaptif.
\end{abstract}

Kata kunci: Respon Kehilangan, Kecemasan dan Lansia

\section{ABSTRACT}

A loss is universally events that are unique to each individual who had an experience in his life, while the level of anxiety is a manifestation of the perceived loss of response or emotionally experienced by a person with the object of threats that are not so obvious. This research aims to determine the correlation between loss of response and the level of anxiety in the elderly.This research using descriptive analytic design with cross sectional approach. This research was conducted on 27-28 June 2016in Social Residential for Elderly in Jayapura Regency. The sampling technique using total sampling are 43 elderly. The data were obtained using questionnaires and analyzed using Spearman Rho test. The results showed that there were 42 elderly (100\%) as respondents who experienced the loss of responsein Social Residential, where the majority of them 38 elderly (90,5\%) in normal anxiety level and 4 elderly (9,5\%) experienced mild anxiety. Elderly who responds not accepting the losswas 1 elderly (100\%), where experienced mild anxiety.The results showedthere is a significant correlation between loss of responseand the anxiety level of elderlyin Social Residential for Elderly In Jayapura Regency ( $p=0,004)$.Greatexpectations for the elderly may face a loss in an adaptive response.

Keywords: Loss of Response, Anxiety and Elderly.

https://ejournal.stikesjypr.ac.id/ 


\section{PENDAHULUAN}

Menurut Kelly (2012) kecemasan adalah mengenali bahwa suatu peristiwa yang dihadapi oleh seseorang berada diluar jangkauan kenyamanan pada sistem konstruk seseorang. Kecemasan atau anxietymerupakan salah satu bentuk emosi individu yang berkenaan dengan adanya rasa terancam oleh sesuatu, biasanya dengan objek ancaman yang tidak begitu jelas. Kecemasan dengan intensitas wajar dapat dianggap memiliki nilai positif sebagai motivasi, tetapi apabila intensitasnya tinggi dan bersifat negatif dapat menimbulkan kerugian dan dapat mengganggu fisik dan psikis individu yang bersangkutan. Kecemasan dialami secara subjektif dan dikomunikasikan secara interpersonal (Arfian, 2013).

\section{Menurut Yosep (2011),} kehilangan adalah suatu keadaan individu berpisah dengan sesuatuyang sebelumnya ada, kemudian menjadi tidak ada, baik terjadi sebagian atau keseluruhan. Kehilangan adalah kejadian yang universal dan kejadian yang sifatnya unik bagi setiap individual dalam pengalaman hidup seseorang. Individu yang mengalami kehilangan ini ada keinginan untuk mencaribantuan kepada orang lain dan mekanisme koping mempengaruhi kemampuan seseorang untuk menghadapi dan menerimakehilangan (Pradana,

2014).

Menurut World Health Organization (2014), proporsi penduduk di atas 60 tahun di dunia tahun 2000 sampai 2050 akan berlipat ganda dari sekitar $11 \%$ menjadi $22 \%$, atau secara absolut meningkat dari 605 juta menjadi 2 milyar lansia. Indonesia termasuk dalam lima besar negara dengan jumlah lanjutusia terbanyak di dunia.

Berdasarkan sensus penduduk pada tahun 2010, jumlah lanjut usia di Indonesia yaitu 18,1 juta jiwa $(7,6 \%$ dari total penduduk). Pada tahun 2014, jumlah penduduk lanjut usia di Indonesia menjadi 18,781 juta jiwa dan diperkirakan pada tahun 2025, jumlahnya akan mancapai 36 juta jiwa (Kementerian Kesehatan RI,2015).

Berdasarkan data Badan Pusat Statistik Provinsi Papua (2014), lansia umur 60-70 tahun ke atas berjumlah 75.793 jiwa, yang terdir dari lansia berjenis kelamin laki-laki sebanyak 43.960 jiwa dan perempuan sebanyak 31.833 jiwa.Berdasarkan data BKKBN Kabupaten Jayapura tahun 2014, jumlah lansia 60 tahun keatas sebanyak 10.360 jiwa.

Semakin meningkatnya jumlah lanjut usia di Indonesia akan menimbulkan 
permasalahan yang cukup kompleks baik dari masalahfisik maupun psikososial. Prevalensi ansietas(kecemasan) di negara berkembang pada usiadewasa dan lansia sebanyak 50\%. Angka kejadian gangguan ansietas di Indonesia sekitar 39 juta jiwa dari 238 juta jiwa penduduk (Heningsih, 2014).

Hasil penelitian Heningsih (2014), menyimpulkan bahwa banyak lansia mengalami kecemasan kategori sedang. Berdasarkan observasi dan wawancara didapatkan hasil bahwa sebagian besar lansia tidak memiliki banyak aktivitas, kehilangan peran sosial dan hidup terpisah dengan keluarga. Lansia mengatakan sering terbangun pada malam hari, tidak tidur nyenyak, merasakan kaku-kaku di otot, sering berkemih, keluar masuk tempat tidur, duduk bersama-sama tapi saling diam asik dengan perasaan masingmasing, jika berbicara dengan temannya mudah tersinggung dan mudah berkeringat. Dari hasil wawancara Kamis 28 April 2016 bersama Bapak Mugiono salah satu staf pegawai di Panti Bina Sosial, didapatkan data bahwa Panti Bina Lanjut Usia Jayapura memiliki daya tampung 70 orang, namun pada saat pengambilandata hanya terdapat sebanyak 62 orang lansia yang berada di tempat, dengan jumlah laki-laki 22 orang dan perempuan 40 orang. Lansia yang ada di Panti masuk karena tidak diperhatikan dan terganggu dengan keluarga, tidak diperdulikan oleh keluarganya bahkan karena masalah ekonomi. Pada saat melakukan wawancara bersama 3 lansia yang tinggal di Panti, lansia mengatakan keluarganya menganggap ia sudah tiada, keluarga jarang sekali menjenguk dan tidak merasa aman.

Hal ini membuat peneliti tertarik untuk meneliti tentang "Hubungan antara Respon Kehilangan dengan Tingkat Kecemasan pada Lansia di Panti Bina Lanjut Usia Jayapura".

Berdasarkan uraian latar belakang di atas, peneliti merumuskan permasalahan "Adakah Hubungan antara Respon Kehilangan dengan Tingkat Kecemasan pada lansia di Panti BinaLanjut Usia Jayapura 2016?”.

\section{METODE PENELITIAN}

Dalam penelitian ini, peneliti menggunakan jenis penelitian deskriptif analitik dengan pendekatan cross sectional.

Penelitian ini dilakukan di Panti Bina Lnajut Usia Jayapura pada tanggal 27 Juni sampai dengan 28 Juni 2016. Populasi dalam penelitian ini adalah seluruh lansia yang berada di Panti Bina Lanjut Usia Jayapura berjumlah 62 lansia yang terdiri dari 22 orang laki-laki dan 40 orang perempuan. Sampel dalam penelitian ini berjumlah 62 orang, teknik 
pengambilan sampel dalam penelitian ini dengan menggunakan total sampling.

Penelitian ini menggunakan instrumen penelitian denganmenggunakan kuesioner respon kehilangan dan tingkat kecemasan pada lansia.

Analisis bivariat dilakukan untuk mengetahui adakah hubungan antara respon kehilangan dengan tingkat kecemasan. Dengan menggunakan analisis uji statistik Spearmen Rho.

Derajat kepercayaan yang digunakan adalah $95 \%$ dengan a $5 \%$ sehingga jika $p$ value $<0,05$ berarti terdapat hubungan bermakna (Signifikan) antara variabel yang diteliti. Jika $p>0,05$ berarti tidak ada hubungan bermakna antara variabel yang diteliti (Notoatmodjo, 2012).

\section{HASIL PENELITIAN}

\begin{tabular}{ccc}
$\begin{array}{c}\text { Tabel distribusi responden berdasarkan } \\
\text { respon kehilangan }\end{array}$ \\
\hline $\begin{array}{c}\text { Respon } \\
\text { Kehilangan }\end{array}$ & Frekuensi & Presentase \\
\hline $\begin{array}{c}\text { Menerima } \\
\text { Tidak }\end{array}$ & 42 & 97,7 \\
Menerima & 1 & 2,3 \\
\hline Total & 43 & 100 \\
\hline
\end{tabular}

Tabel distribusi responden berdasarkan
Tabel distribusi responden berdasarkan tingkat kecemasan

\begin{tabular}{ccc}
\hline $\begin{array}{c}\text { Tingkat } \\
\text { Kecemasan }\end{array}$ & Frekuensi & Presentase \\
\hline Normal & 38 & 88,4 \\
Ringan & 5 & 11,6 \\
Sedang & 0 & 0 \\
Berat & 0 & 0 \\
\hline Total & 43 & 100 \\
\hline
\end{tabular}

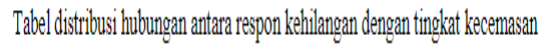

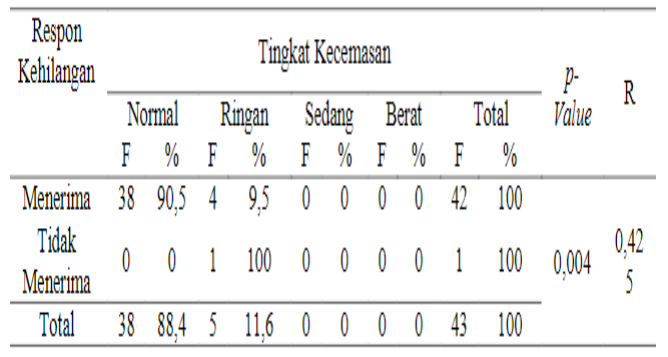

\section{PEMBAHASAN}

\section{Respon Kehilangan}

Berdasarkan hasil penelitian yang diketahui bahwa sebagian besar responden yang merespon kehilangan dalam kategori menerima sebanyak 42 orang $(97,7 \%)$, dan hanya 1 orang lansia $(2,3 \%)$ yang berada pada kategori tidak menerima. Kehilangan merupakan suatu keadaan gangguan jiwa yang biasa terjadi pada orang-orang yang menghadapi suatu keadaan yang berubah dari keadaan semula (Pradana, 2014).

Situasi emosi sebagai respon kehilangan seorang individu berada dalam rentang yang fluktuatif, dari tingkatan yang adaptif sampai dengan 
maladaptif (Yusuf dkk, 2015). Salah satu jenis kehilangan adalah kehilangan seseorang yang dicintai. Kematian juga membawa dampak kehilangan bagi orang yangdicintai. Karena keintiman, intensitas dan ketergantungan dari ikatan atau jalinan yang ada, kematian pasangan suami/istri atau anak biasanya membawa dampak emosionalyang luar biasa dan tidak dapat ditutupi (Utari, 2014).

Menurut Yusuf dkk (2015) ada 5 rentang respon individu terhadap kehilangan yaitu penyangkalan (denial), marah (anger), penawaran(bargaining), depresi (depression) dan penerimaan(acceptance). Berdasarkan data yang didapatkanbahwa kebanyakan lansia yang merespon kehilangan dengan menerima, hal ini menunjukkan bahwa lansia sudah bisa beradaptasidan menyesuaikan diri dengan lingkungan tempat lansia berada serta lansia mulai menerima perpisahan dengan keluarga.

\section{Tingkat Kecemasan}

Berdasarkan hasil penelitian yang diketahui bahwa sebagian besar responden dengan tingkat kecemasan normal sebanyak 38 orang $(88,4 \%)$ dan lansia dengan tingkat kecemasan ringan sebanyak 5 orang $(11,6 \%)$.

Tingkat KecemasanBerdasarkan hasil penelitian yang diketahui bahwa sebagian besar responden dengan tingkat kecemasan normal sebanyak 38 orang $(88,4 \%)$ dan lansia dengan tingkat kecemasan ringan sebanyak 5 orang $(11,6 \%)$.Kecemasan adalah suatu keadaan aprehensi atau keadaan khawatir yang mengeluhkan bahwa sesuatu yang buruk akan terjadi (Guntara, 2015).Berdasarkan kuesioner tingkat kecemasan dapat dilihat bahwa banyak responden yang memilih jawaban muka cepat panas dan usam, tangan dan kaki sering merasa gematar, terganggu dengan sakit kepala, leher dan pinggang saat merasa cemas. Hal ini dapat disesuaikan dengan pendapat Hawari (2011), yang menyatakan keluhankeluhan yang sering dikemukakan oleh orang yang mengalami gangguan kecemasan antara lain: rasa sakit padaotot dan tulang dan sakit kepala.

Kecemasan adalah suatu keadaan aprehensi atau keadaan khawatir yang mengeluhkan bahwa sesuatu yang buruk akan terjadi (Guntara, 2015).

Berdasarkan nilai koefisien korelasi 0,425 keeratan hubungan antara dua variabel memiliki keeratan kuat, karena kriteria keeratan hubungan dianggap kuat jika koefisien korelasi $(\mathrm{r})=0,41$ sampai 0,70 .

Berdasarkan kuesioner tingkat kecemasan dapat dilihat bahwa banyak 
responden yang memilih jawaban muka cepat panas dan usam, tangan dan kaki sering merasa gematar, terganggu dengan sakit kepala, leher dan pinggang saat merasa cemas. Hal ini dapat disesuaikan dengan pendapat Hawari (2011), yang menyatakan keluhan-keluhan yang sering dikemukakan oleh orang yang mengalami gangguan kecemasan antara lain: rasa sakit pada otot dan tulang dan sakit kepala.

\section{Analisa Bivariat}

Hubungan antara Respon Kehilangan dengan Tingkat Kecemasan pada Lanjut Usia Berdasarkan hasil uji statistik dengan menggunakan Spearman's rho diketahui hubungan tingkat respon kehilangan dengan tingkat kecemasan pada lansia didapatkan nilai koefisien korelasi 0,425 dan taraf signifikansi sebesar $0,004<\left(p\right.$ 0,005), maka $\mathrm{H}_{0}$ tolak dan $\mathrm{H}_{1}$ diterima artinya terdapat hubungan antara respon kehilangan dengan tingkat kecemasan pada lansia diPanti Bina Lanjut Usia.

Sesuai kuesioner respon kehilangan kebanyakan lansia yang menjawab pernyataan tentang lansia tidak pernah menyalahkan orang lain akibat berpisah dari keluarga, mulai percaya keberadaannya, mulai menerima, tidak marah jika keluarga tidak menjenguk dan memiliki perasaan yang cukup baik. Hal ini menunjukkan bahwa lansia mulai menerima keadaan mereka di Panti dan merasa nyaman

Berdasarkan nilai koefisien korelasi 0,425 keeratan hubungan antara dua variabel memiliki keeratan kuat, karena kriteria keeratan hubungan dianggap kuat jika koefisien korelasi $(r)=0,41$ sampai 0,70 . Hal ini berarti bahwa ada hubungan yang kuat antara respon kehilangan dengan tingkat kecemasan dan diperoleh arah korelasinya positif, yang berarti jika respon kehilangan mengalami kenaikan maka tingkat kecemasan juga akan mengalami kenaikan, sebaliknya jika respon kehilangan mengalami penurunan maka tingkat kecemasan juga akan mengalami penurunan. Adanya hubungan yang saling mempengaruhi tersebut didasarkanpada data yaitu dari 42 lansia yang merespon kehilangan dengan kategori menerima, 38 lansia yang mengalami kecemasan normal dan 4 yang dalam kategori kecemasan ringan. Hal ini disebabkan karenalansia mampu menerima kenyataan terhadap kehilangan, sesuai dengan teori Yusuf dkk (2015) mengatakan bahwa individu yang berada pada tahap penerimaan fokus pemikiran terhadap sesuatu yang hilang mulai berkurang. 
Berdasarkan penelitian Widyowati (2013), bahwa lansia kematian suami atau istri, para lansia menemukan sosok lain yang dijadikan sebagai tempat bertukar pikiran seperti anak, teman sebaya, dan sebagainya. Secara umum para lansia juga sudah merasa bahagia, puas, dan tidak memiliki keinginan lain yang ingin dicapai dalam hidup, mereka lebih suka melanjutkan aktifitas yang selama ini telah mereka kerjakan baik saat suami atau istri masih hidup ataupun telah meninggal, para lansia juga ingin melewati masa tua dengan perbuatan yang lebih baik dan bermanfaat bagi diri mereka karena memandang bahwa suatu saat kematianpun akan datang pada mereka.

Penerimaan terhadap kenyataan kehilangan mulaidirasakan, sehingga sesuatu yang hilang tersebut mulai dilepaskan secara bertahap dan dialihkan kepada objek lain yang baru. Sesuai kuesioner respon kehilangan kebanyakan lansia yang menjawab pernyataan tentang lansia tidak pernah menyalahkan orang lain akibat berpisah dari keluarga, mulai percaya keberadaannya, mulai menerima, tidak marah jikakeluarga tidak menjenguk dan memiliki perasaan yang cukup baik.

Hal ini menunjukkan bahwa lansia mulai menerima keadaan mereka di Panti dan merasa nyaman, dimana hal tersebut dapat diketahui dari lansia yang lebih menyibukkan diri dengan kegiatan di lingkungan Pantiyaitu mengikuti kegiatan pelayanan bimbingan sosial, psikososial, mental, spiritual, keterampilan rekreasi dan hiburan. Selain itu, lebih suka mengalihkan masalah daripada memikirkan dan menghadapi secara langsung, acuh terhadap situasi yang tertekan, tidak mau ambil pusing, dan memilih untuk diam saat menghadapi masalah, serta berdoa dengan harapan bahwa masalahny akan segera selesai.Dari hasil penelitian 1 lansia yang merespon kehilangan dengan kategori tidak menerima dan berada dalam kategori kecemasan ringan. Hal ini disebabkan karena lansia belum bisa menyesuaikan diri, dapat dilihat pada kuesioner respon kehilangan bahwa lansia sering merasakan gelisah, berhalusinasi dan merasa tidak nyaman.

Hal ini sesuai dengan teori bahwa kehilangan pada seseorang dapat memiliki berbagai dampak kehilangan khususnya kematian pasangan hidup dapat menjadi pukulan yang sangat berat dan menghilangkan semangat hidup orang yang ditinggalkan (Hidayat dan Uliyah, 2012).

Berdasarkan teori tersebut maka lansia yang respon kehilangan dapat mempengaruhi tingkat kecemasan lansia 
karena kecemasan juga berhubungan dengan perkembangan trauma seperti perpisahan dan kehilangan. Traumatik yang sangat membekas di masa lalu sangat berpotensi menyebabkan emosi di kemudian hari.

Keberadaan keluarga di masamasa lanjut usia merupakan bagian yang sangat diharapkan kebanyakan orang, namun dengan perubahan- perubahan yang dialami oleh lansia baik fisik maupun mental membawa dampak dimana orang lanjut usia tidak dapat lagi tinggal bersama keluarga baik itu sengaja maupun tidak sengaja (Siahaan 2012)

$$
\text { Dari hasil penelitian }
$$
Puspitaningsih (2014), bahwa kenyataan yang terjadi di Panti Werdha Mojopahit Mojokerto terdapat permasalahan sosial seperti mereka sering menyendiri, jarang bergaul dengan teman-temannya dan mereka kelihatan tidak nyaman tinggal di Panti. Apabila lansia tersebut tidak segera mampumenyesuaikan diri dengan lingkungan baru dan berusaha menjalin hubungan dengan orang lain yang seusianya. Kecemasan akan muncul, kecemasan yang berkepanjangan tidak menutup kemungkinan lansia akan mengalami keputusasaan. Sesuai dengan teori Prasetyo (2013) bahwa lansia tersebut harus beradaptasi atau menyesuaikan diri dengan kelompok seusianya.

Sehubungan dengan kematian pasangan, terpisahnya dengan keluarga, permasalahan yang dihadapi oleh para lansia yang ditinggal mati pasangan atau keluarganya antara lain: kesepian, kerinduan akan kebersamaan dulu dengan keluarganya dan merasa sendirian ketika harus mengatasimasalah yang datang.

Salah satu jenis kehilangan adalah kehilangan seseorang yang dicintai.Kematian juga membawa dampak kehilangan bagi orang yang dicintai.Karena keintiman, intensitas dan ketergantungan dari ikatan atau jalinan yang ada,kematian pasangan suami/istri atau anak biasanya membawa dampak emosionalyang luar biasa dan tidak dapat ditutupi.

Penerimaan terhadap kenyataan kehilangan mulai dirasakan, sehingga sesuatu yang hilang tersebut mulai dilepaskan secara bertahap dan dialihkan kepada objek lain yang baru. Sesuai kuesioner respon kehilangan kebanyakan lansia yang menjawab pernyataan tentang lansia tidak pernah menyalahkan oranglain akibat berpisah dari keluarga, mulai percaya keberadaannya, mulai menerima,tidak marah jika keluarga tidak menjenguk dan memiliki perasaan yang 
cukup baik.

Menurut Stuart (2012), kecemasan dipengaruhi oleh faktor eksternal yaitu ancaman terhadap sistem diri dapat membahayakan identitas, harga diri dan fungsi sosial yang terintegrasi pada individu. Hal ini menunjukka kurangnya dukungan sosial dapat mempengaruhi sumber koping individu,dimana ketidakhadiran keluarga atau orang lain dapat menyebabkan seseorang merasa cemas.

\section{KESIMPULAN}

Respon Kehilangan pada lansia di Panti Bina Lanjut Usia Jayapura sebagian besar lansia yang menerima sebanyak 42 orang $(97,7 \%)$ dan yang tidak menerima sebanyak 1 orang $(2,3 \%)$.

1. Tingkat Kecemasan pada lansia di Panti Bina Lanjut Usia Jayapura sebagian besar lansia dengan tingkat kecemasan normal sebanyak 38 orang $(88,4 \%)$ dan lansia dengan tingkat kecemasan ringan sebanyak 5 orang $(11,6 \%)$.

2. Ada hubungan antara respon kehilangan dengan tingkatkecemasan pada lansia di Panti Bina Lanjut Usia Jayapura dengan nilai $p$-value $(0,004)<(0,05)$ dan koefisien korelasisebesar 0,425 sehingga dapat dinyatakan keeratan hubungan antara dua variabel memiliki keeratankuat.

\section{SARAN}

Bagi Panti Bina Lanjut Usia Diharapkan bagi Panti Bina Lanjut Usia agar dapat memberikan keamanan dan kenyamana pada lansiakhususnya penyediaan Satpam/Pos penjagaan.

1. Bagi Lanjut Usia

Diharapkan bagi lanjut usia dapat untuk menghadapi respon kehilangan secara adaptif yaitu dengan berani terbuka untuk kehilangan dan mampu membuat rencana untuk kehidupannya yang akan datang.

\section{Bagi Tenaga Kesehatan}

Diharapkan dapat menambah pengetahuan bagi perawat gerontik untuk memberi asuhan keperawatan pada lansia untukmencegah terjadiny dampak yang buruk pada lansia Lanjut Usia Jayapura.

\section{Bagi Peneliti}

Diharapkan dapat menambah pengalaman dan wawasan bagi peneliti dan sebagai sumber referensi bagi peneliti selanjutnya.

\section{DAFTAR PUSTAKA}

Arfian. (2013).KTI Kecemasan BAB II.http://liyanzaruki.blogspot. com. Diakses 3 Mei 2016.

BKKBN. (2014). Rekapitulasi Hasil Pendataan Keluarga Tingkat 
Kabupaten.Jayapura:BKKBN

BPS Provinsi Papua. (2014). Рариа dalam Angka 2015.

Http://papua.bps.go.id. Diakses 2 Mei 2016.

Guntara, H.(2015). Hubungan antara

Konsep Diri dengan Kecemasan

Memulai Mengerjakan Skripsi pada

Mahasiswa

FakultasPsikologi

Universitas Muhammadiyah.

Hidayat, A., dan Uliyah, M. (2011). Buku Ajar: Ketrampilan Dasar Praktik Klinik untuk Pendidikan Kebidanan. Surabaya:Health Book Publishing. Kelly. (2012).Kecemasan.

http://threeonamillion.blogsp ot.com. Diakses 2 juni 2016. Kementerian Kesehatan RI. (2015). Pelayanan dan Peningkatan Kesehatan Usia Lanjut. Http://www.depkes.go.id. Diakses 2 Juni 2016.

Notoatmodjo, S. (2012). Metodologi Penelitian Kesehatan. Jakarta: Rineka Cipta

Pradana, B. (2014).Askep Kehilangan. http://diaryforberti.blogspot.c om. Diakses 29 Mei

2016. Prasetyo. (2013). Well-Being ada Lansia yang Tinggal di Panti Werdha atas Dasar Keputusan Sendiri. Jurnal Fakultas Psikologi Universitas Katolik Widya Mandala Surabaya.
Surakarta: Program Studi S-1Psikologi.

Hawari, D. (2011). Manajemen Stres Cemas dan Depresi. Jakarta: Balai Penerbit FKUI. Heningsih. (2014). GambaranTingkat Ansietas pada Lansia di Panti Wredha

Dharma Bhakti Kasih. Surakarta: Program Studi S-1 Keperawatan. Stikes Kusuma Husada

Puspitaningsih, D. (2014). Adaptasi Diri padaLansiadiPanti Werdha Mojopahit Mojokerto. Jurnal. Vol 6. Diunduh 5 September 2016.

Siahaan, R. L. (2012). Evaluasi Pelaksanaan ProgramPelayanan Lansia di Unit Pelaksanaa Teksisi Tuna Rung Wicara dan Pelayanan sosial. Jurnal. http://digilib.stikeskusumahu sada.ac.id. Diunduh 11Agustus 2016.Utari, A. (2014).

ASKEP Kehilangan dan Berduka. http://anatasiachacha.blogspo t.co.id. Diakses 29 Mei 2016. Widyowati, W. (2013). Resiliensi pada Lansia yang Ditinggal Mati Pasangan Hidupnya.

Jurnal. Surakarta: Fakultas Psikologi UniversitasMuhammadiyah. 
Yosep, I. (2011). Keperawatan Jiwa.

(Edisi Revisi). Bandung: Refika

Aditama.

Yusuf. Ah., dkk. (2015). Buku Ajar

Keperawatan Kesehatan Jiwa. Jakarta:

Salemba Medika. 